\title{
The effect of FDI on low and high-skilled employment and wages in Mexico: a study for the manufacture and service sectors
}

\author{
Eduardo Saucedo ${ }^{1 *} \mathbb{D}$, Teofilo Ozuna Jr. ${ }^{1}$ and Hector Zamora ${ }^{2}$
}

\begin{abstract}
This study analyzes the effect of Foreign Direct Investment (FDI) inflows on the employment and wages of low- and high-skilled employees in the manufacture and service sectors in Mexico. The study implements a quarterly panel dataset covering the 32 Mexican states from 2005 to 2018. The econometric model is estimated throughout FixedEffects (FE) and Panel Corrected Standard Errors (PCSE). Employment results indicate that an increase of FDI inflows into the manufacture sector creates a positive effect in low- and high-skilled employment. In the case of service sector, results are inconclusive across models for both categories of employment. In the case of wages, it is found that FDI inflows by the manufacture sector increase marginally in low-skilled wages and no statistical effect is captured in high-skilled wages. Lastly, in service sector, results indicate the effect of FDI inflows are inconclusive in the case of lowskilled and high-skilled wages.
\end{abstract}

Keywords: Foreign Direct Investment, Employment, Mexico, Panel data

JEL Classification: F21, F23, F36, J21, J23, R10

\section{Introduction}

In its World Investment Reports (UNCTAD 2016, 2017, 2018), the United Nations Conference on Trade and Development (UNCTAD) mentioned that Mexico is considered the primary driver of Foreign Direct Investment (FDI) growth in Central America, where the country has participated with approximately $70 \%$ of the total FDI inflows to this region in the last years. Nevertheless, the 2017 and 2018 investment reports for Mexico were not very optimistic (UNCTAD 2017, 2018), since FDI inflows in 2016 and 2017 reached $\$ 30$ billion dollars each year, which is $15 \%$ below the amount received in 2015. Such contraction was mainly explained by the uncertainty that existed at that time about the future of the North

\footnotetext{
${ }^{*}$ Correspondence: eduardo.saucedo@tec.mx

${ }^{1}$ EGADE Business School, Tecnologico de Monterrey, Ave. Rufino Tamayo,

CP. 66269 Garza Garcia, NL, Mexico

Full list of author information is available at the end of the article
}

American Free Trade Agreement (NAFTA), now called United States-Mexico-Canada Agreement (USMCA).

Waldkirch (2010) states that Mexico has been actively trying to attract FDI since the 1980 s by relaxing investment restrictions on different economic sectors. In addition, since 1994, NAFTA benefited Mexico as it substantially and permanently increased FDI inflows into the country. As a result, abundant FDI came into the country seeking to exploit Mexico's comparative advantage (Waldkirch 2011). Given the relevance of FDI in the economy since the implementation of NAFTA, abundant literature has emerged analyzing the effects of FDI on different economic variables, such as wages, labor productivity, and employment. Diverse literature has also emerged analyzing the impact of NAFTA on economic sectors, such as manufacturing, maquiladora industry, and the impact on different economic regions in the country. 
Nevertheless, the existing literature about Mexico has paid limited attention to analyze the effect of FDI on employment and wages in the manufacturing and service sectors, even though those two economic sectors have received together around $75 \%$ of total FDI inflows that had come into the country since 2005 . The scarcity of studies in the field is more noticeable if it is analyzed by the effect of FDI inflows on employment and wages when separating employment in the two categories (low-skilled and high-skilled). Such studies could be of relevance and interest for policy makers, since the design of policies can be focused on the groups that are considered a priority for a country or a government.

The study helps fill the gap in the literature by analyzing employment and wages of low- and high-skilled employees in the manufacturing and service sectors, which according to the number of employees and FDI inflows received in the country, are the two most relevant sectors in the economy. This study is performed using data for each of the 32 states in Mexico, covering the period from 2005 to 2018 at the sub-national level in Mexico. The econometric model implemented in this study is similar to the one used by Hanson (2001), but with a small variation to examine the impact of FDI on low-skilled and high-skilled employment and wages. To obtain the coefficient estimates, a Fixed-Effects model (FE) and a Panel Corrected Standard Errors (PCSE) model are developed and estimated. Results indicate that, in most scenarios, FDI inflows have different effects on low-skilled and high-skilled employment in manufacturing and service sectors.

The remainder of this study is organized as follows: Section 2 provides important background on FDI inflows and their effects on employment and wages. Section 3 describes the econometric model implemented in this study. Section 4 introduces the dataset and explains the distribution of FDI and employment in manufacturing and service sectors around the country. Section 5 discusses the results of the estimated regression, and the last section presents the conclusion of this study.

\section{Literature review}

Most studies available in the literature which analyze the effects of the FDI inflows on the local economy, commonly mention that FDI inflows bring new and more sophisticated technology into the host economy, expand firms' production capabilities, and create some effects on employment, wages and labor productivity. In addition, an important portion of the literature has focused on categorizing employees according to skill levels and analyzing the effect of FDI inflows on the wages of those different categories of employees. Girma et al. (2002), Owen and Yu (2008), Pandya (2010), Hanousek et al. (2011),
Onaran (2012), Lee and Wie (2015) and Bogliaccini and Egan (2017), are examples of studies which analyze the effect of FDI on low- and high-skilled local wages.

Another set of the literature analyzes exclusively the effect of FDI inflows on low- and high-skilled employment in the host economies. Studies such as Bailey and Driffield (2007), Blanton and Blanton (2012), Raouf and Hafid (2014), Yunus et al. (2015) are examples of this. Lastly, some other literature is just interested in analyzing if FDI inflows have a general positive or negative effect on local employment. Studies such as Radosevic et al. (2003), Waldkirch et al. (2009), Villa (2010), Inekwe (2013) and Bandick and Karpaty (2011) are examples of studies which find that the effect of FDI on employment is positive. On the other hand, Girma (2005) and Jenkins (2006), find that FDI inflows have a negative impact on local employment.

\subsection{Literature about the effect of FDI on employment and wages in Mexico}

In a pioneer study for the Mexican economy, Feenstra and Hanson (1997) study the impact of FDI on the wages of skilled labor in Mexico over the period 1975-1988. They measure FDI using regional data on foreign assembly plants and conclude that FDI growth is positively correlated with the relative demand for skilled labor, which at the same time has influenced the increase of wages in regions where FDI has concentrated.

Some other studies have been also focused on the effect of FDI on employment according to the skill level. For example, Nunnenkamp and Bremont (2007) estimate dynamic labor demand functions for blue-collar (lowskilled) and white-collar (high-skilled) workers in Mexico for the period 1994-2006. Their findings do not support the widely-held view that FDI inflows add to white-collar employment. However, the positive effect on blue-collar employment diminishes when increasing skill intensity in manufacturing industries. Waldkirch et al. (2009) in a study on employment of non-maquiladora manufacturing activities, find that FDI has a statistically significant and positive effect on both blue and white-collar manufacturing employment. Later, Waldkirch (2010) suggests that wages may be negatively affected by FDI, particularly in maquiladoras, because large FDI tend to reduce skilled wages. Some other studies, such as Turner and Martínez (2003) and Loría and Brito (2005) associate FDI received by multinationals that operate in Mexico with an increase in employment in the country especially in the manufacture sector. Lastly, Vergara et al. (2015) analyze the effect of FDI on five industrial sectors in the northern region of Mexico during the period from 2004 to 2013, and they find a positive correlation between FDI and employment only in the electricity sector. 


\section{Econometric model}

The generic labor market supply and demand equations proposed by Hanson (2001) are used in this study to investigate the effects of FDI on low-skilled and highskilled employment. The reduced-form equations from such model have the following form:

$$
\begin{aligned}
& L n L_{j t}^{k}=\beta \ln W_{j t}^{A, k}+A_{j t} \alpha_{1}+B_{t} \alpha_{2}+C_{t} \alpha_{3}+\vartheta_{j t} \\
& L n W_{j t}^{k}=\lambda \ln W_{j t}^{A, k}+A_{j t} \eta_{1}+B_{t} \eta_{2}+C_{t} \eta_{3}+\mu_{j t} .
\end{aligned}
$$

Equations (1) and (2) can be obtained by assuming that both labor supply and labor demand are in equilibrium. The terms $A, B$, and $C$ represent vectors related to state, country, and international conditions, respectively. The superscript $\mathrm{k}$ refers to low- or high-skilled categories, while the subscript $j$ and $t$ refer to each of the 32 Mexican states and the quarterly periods during 2005-2018. Additionally, $W$ represents wages, and $W^{A}$ stands for alternative wages. Briefly, an alternative wage for state $j$ is a weighted average of wages in every state except state $j$. The terms $\alpha_{1}-\alpha_{3}$, and $\eta_{1}-\eta_{3}$ are vectors of parameters; $\beta$ and $\lambda$ are scalar values; and $\vartheta_{j t}$ and $\mu_{j t}$ are error terms assumed to be independent and identically distributed with zero mean and constant variance.

Equations (1) and (2) are estimated in this study throughout different econometric models. Breusch and Pagan Lagrangian multiplier test indicates that the use of panel data techniques is more appropriate than OLS and, similarly, the Hausman test allows to indicate that the use of fixed effects is preferable to random effects in the estimation of both equations. Therefore, tables only show the estimates for fixed effects. Additionally, the possibility of the existence of the classic problems of data panels is considered. The results of the Wooldridge tests to prove the existence of serial correlation in the estimates, as well as a modified Wald test to check for the presence of heteroskedasticity, and a BreuschPagan test to identify contemporary correlation problems in the residuals, suggest that it is necessary to correct all of the problems. Moreover, endogeneity problems were tested with the $\mathrm{C}$ statistic, yet no evidence was found to state that the estimations should be corrected for endogeneity.

In Cameron and Trivedi (2010), the use of Feasible Generalized Least Squares (FGLS) and Panel Corrected Standard Error (PCSE) is recommended for data panels where $\mathrm{T}$ is greater than $\mathrm{N}$ (in this study $\mathrm{T}=56$ and $\mathrm{N}=32$ ). However, Beck and Katz (1995) demonstrate that FGLS produces results with strongly underestimated standard errors and, through Monte Carlo simulations, they find that PCSE produces more accurate results of standard errors, with zero or little loss of efficiency, compared to FGLS. Thus, in this study, the problems previously mentioned are addressed using PCSE. Additionally, for comparison purposes, fixed effects regression results are shown.

\section{Data}

The dataset covers the 32 Mexican states on a quarterly basis from 2005 to 2018. Data are drawn from the Mexican Institute of Statistics, Geography, and Information (INEGI), which collects the dataset for employment and wages via the National Survey of Occupation and Employment (ENOE). Similarly, INEGI includes the dataset for population and the Ministry of Economy keeps track of FDI inflows.

As aforementioned, this study focuses on analyzing the effect of FDI inflows on different low- and high-skilled categories in employment and wages in the manufacturing and service sectors. Table 6 in Appendix shows the average employment distribution for low- and highskilled employment for the manufacture and service sectors for each of the Mexican states during the period from 2005 to 2018, which is the period analyzed in this study. It can be observed that Estado de Mexico and Mexico City are the places that most capture employment, either low- or high-skilled employment either in the manufacture or service sectors. Those two states together capture around $25 \%$ of the total high-skilled employment in manufacture and service sectors in the country. Similarly, Table 6 shows that the top five states, as a group, capture around $50 \%$ of high-skilled employment in the country, while the bottom five states in the table capture around $5 \%$ of the high-skilled employment in the country, either in the manufacture or service sectors. In the case of the low-skilled employment; shares are less concentrated on the top states and are slightly better distributed across all Mexican states.

Table 7 in Appendix section shows the average monthly salaries in real terms $(2013=100)$ for the low- and highskilled employees working in the manufacture and service sectors in each of the Mexican states during 2005-2018. The manufacture sector shows an important dispersion in salaries between low- and high-skilled employees. For example, the highest salaries in the high-skilled manufacture sector are in Coahuila, registering $\$ 7549$ real Mexican pesos, a value $76 \%$ higher than the highest low-skilled salaries in the manufacture sector in Baja California, with $\$ 4301$ real Mexican pesos per month. It is worth identifying that some states have high-skilled salaries which are above the country's average, but at the same time those same states report low-skilled salaries below the country average; this is observed in Guanajuato, Colima, Jalisco, 
Table 1 Total country FDI 2005-2018; Percentage total FDI. Source: Own estimations using data from the Ministry of Economy

\begin{tabular}{lcccccccccccccc}
\hline & $\mathbf{2 0 0 5}$ & $\mathbf{2 0 0 6}$ & $\mathbf{2 0 0 7}$ & $\mathbf{2 0 0 8}$ & $\mathbf{2 0 0 9}$ & $\mathbf{2 0 1 0}$ & $\mathbf{2 0 1 1}$ & $\mathbf{2 0 1 2}$ & $\mathbf{2 0 1 3}$ & $\mathbf{2 0 1 4}$ & $\mathbf{2 0 1 5}$ & $\mathbf{2 0 1 6}$ & $\mathbf{2 0 1 7}$ & $\mathbf{2 0 1 8}$ \\
\hline $\begin{array}{l}\text { Total FDI } \\
\text { (Millions of dollars) }\end{array}$ & 26,013 & 21,124 & 32,477 & 29,468 & 18,066 & 27,260 & 25,601 & 21,191 & 48,399 & 29,879 & 35,775 & 30,534 & 32,915 & 32,694 \\
$\begin{array}{l}\text { Manufacture } \\
\text { (\% Total FDI) }\end{array}$ & $51.5 \%$ & $52.9 \%$ & $42.5 \%$ & $31.3 \%$ & $39.8 \%$ & $52.8 \%$ & $44.8 \%$ & $44.4 \%$ & $64.8 \%$ & $61.8 \%$ & $49.3 \%$ & $57.3 \%$ & $45.5 \%$ & $48.3 \%$ \\
$\begin{array}{l}\text { Services } \\
\text { (\% Total FDI) }\end{array}$ & $27.9 \%$ & $38.9 \%$ & $36.5 \%$ & $37.9 \%$ & $38.7 \%$ & $24.7 \%$ & $32.5 \%$ & $8.4 \%$ & $12.1 \%$ & $10.0 \%$ & $20.6 \%$ & $19.6 \%$ & $15.4 \%$ & $14.2 \%$ \\
$\begin{array}{l}\text { Other } \\
\text { (\% Total FDI) }\end{array}$ & $20.6 \%$ & $8.2 \%$ & $21.0 \%$ & $30.8 \%$ & $21.5 \%$ & $22.5 \%$ & $22.7 \%$ & $47.2 \%$ & $23.1 \%$ & $28.2 \%$ & $30.2 \%$ & $23.1 \%$ & $39.1 \%$ & $37.5 \%$ \\
\hline
\end{tabular}

Durango, to mention a few. In the case of the service sector, the state with the highest high-skilled salaries in this sector is Baja California Sur (touristic place) with $\$ 7696$ per month, while its neighbor, the state of Baja California, shows the highest salaries for low-skilled workers with $\$ 4538$.

Table 1 shows the total FDI received in the country in every year analyzed in this study and the percentage that manufacture and service sectors represent in the total FDI. On the one hand, the lowest value received in FDI in the country is observed in 2009, during the economic crisis when the country received 18,000 million dollars. On the other hand, the highest value is observed in 2013, when the country received more than 48,000 million dollars. It is worth mentioning that the manufacture sector has been historically the economic sector with the highest volumes of FDI inflows into the country. The lowest values appear also during the 2008 economic crisis, when Mexico captured $31 \%$ of the total FDI, and the highest value is observed in 2013, when almost $65 \%$ of the total FDI came into the country. Regarding the service sector, the lowest value appears in 2012, when it captured 8.4\%, and the highest appeared from 2006 to 2009, when the value ranged around $38 \%$ of the total FDI received in the country.

Figure 1 illustrates how FDI in the manufacturing and service sectors has been distributed across the country during the period 2005-2018. As it can be seen above, in maps $1 \mathrm{a}$ and $2 \mathrm{a}$, the "white" states are those which received the least amount of FDI either in the manufacturing or service sectors during the entire period. In fact, all the "white" states captured less than $1 \%$ of the total FDI received by each sector in the whole period. Out of the country's 32 states, there are 14 "white" states in Fig. 1a, all of which, as a group, captured $5.5 \%$ of the total FDI in the manufacturing sector received in the country during the 2005-2018 period. In the case of Fig. 2a, the 14 states in "white" captured, as a group, $7.8 \%$ of the total FDI received in the country in the service sector in the entire period.
In the case of "light grey" states, they captured more than $1 \%$, but less than $4 \%$ of the total FDI received in the country in each respective sector. In the case of the manufacturing sector, there are 8 states out of 32 in "light grey" which, as a group captured around $20 \%$ of the total FDI received in the country in the analyzed period. In the case of the service sectors, there are 8 states, which accounted for $12 \%$ of the total FDI received in the country in the aforementioned sector. Lastly, the 10 "dark grey" states accounted for $70 \%$ of the total FDI received in the manufacturing sector and $80 \%$ of the FDI received in the service sector. Figures $1 \mathrm{~b}$ and $2 \mathrm{~b}$ show the FDI received by the top five states in each sector in the entire period. These five states captured $49 \%$ in the manufacturing sector and $65 \%$ in the service sector. These numbers confirm that FDI in both sectors is highly concentrated in a few states. Lastly, Fig. 2 in Appendix section captures how FDI evolved in each of the states in the country during the entire period analyzed in the study.

Table 2 presents descriptive statistics for all variables used in this paper. The effect of FDI upon employment and wages, both disaggregated in low-skilled and highskilled, are the main variables of interest in this study; therefore, FDI is broken down into two different FDI categories. As previously discussed, this paper explores the effect of FDI on different kinds of employment and wages. For such reason, the dependent variables in the regression model are low-skilled employment and wages in the manufacturing and service sectors, as well as highskilled employment and wages in the manufacturing and service sectors.

As mentioned earlier, the main independent variable is FDI inflows into the country. With regards to the Ministry of Economy's FDI classification, FDI database is divided in the following categories: new FDI, FDI originated from the reinvestment of profits, and FDI between companies related to transactions made between domestic and foreign companies. New FDI refers to investment that comes exclusively into the country to expand production and is expected to have a direct impact on employment. 


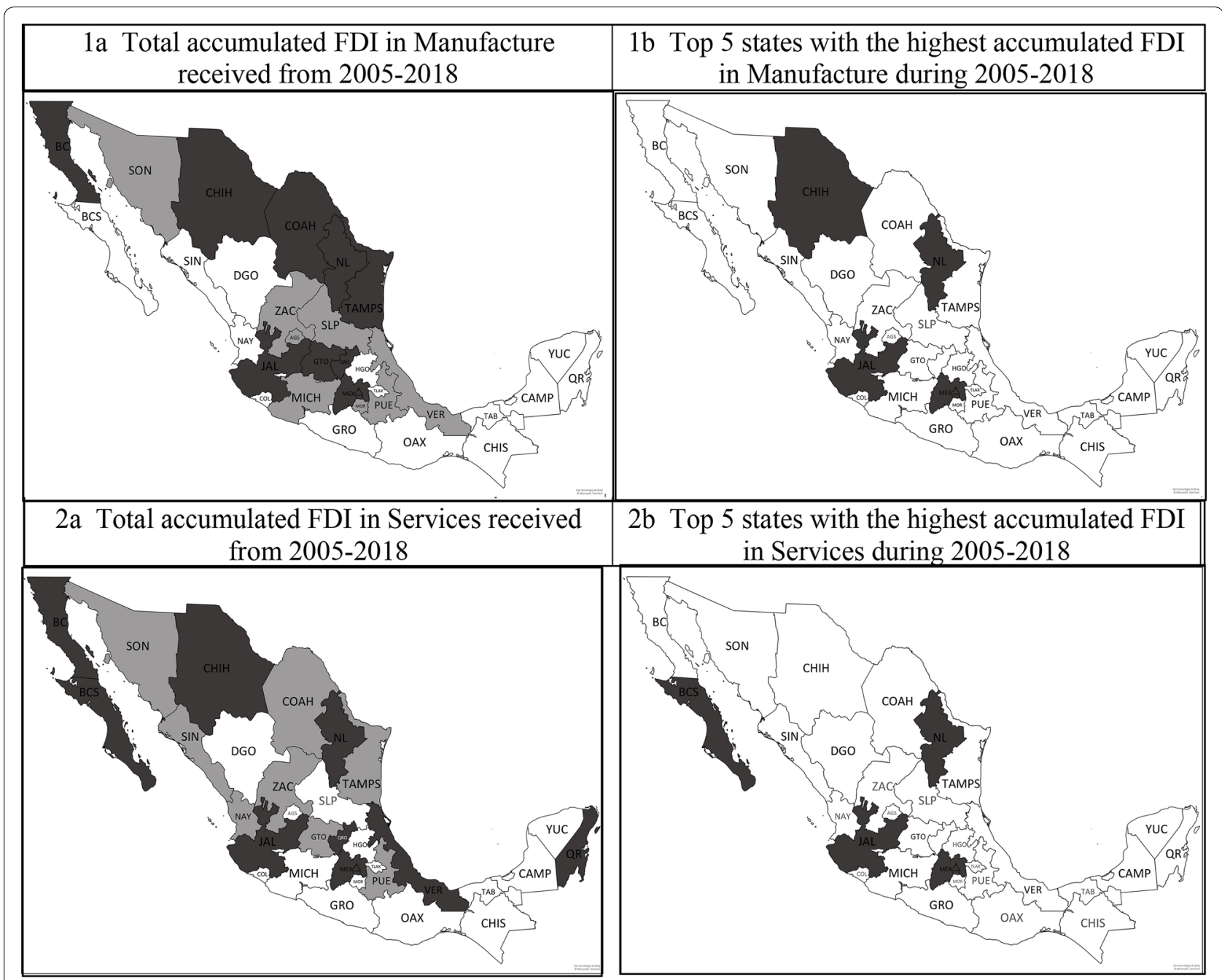

Fig. 1 Geographic distribution of accumulated FDI by sectors, 2005-2018 (Source: Own estimates using data from the Ministry of Economy)

Vergara et al. (2015) and Cabral et al. (2016); both papers focus on the analysis of new FDI inflows among all FDI categories, which is more related with employment. The main independent variable is available in US dollars, so FDI is transformed to real pesos $(2013=100)$ by considering the nominal exchange rate for the period, and then a deflator is built based on the 2013 consumer price index from INEGI.

Once FDI inflows are analyzed at state level, it is found that Mexico City has received the highest amount of FDI inflows in the entire nation, reaching up to $19.1 \%$ of the total FDI inflows received in the country during the 2005-2018 period. It is important to mention that such numbers can produce a bias in the analysis because, in many cases, headquarters of companies are in Mexico City, which is the capital of the country, and those headquarters receive the money to be invested, but such money (FDI flows) could be invested in a different place in the country. We identify this issue in our data, but this is the only data available about FDI state inflows, hence there is no way to eliminate such potential bias. Bellak (1998), Jordaan (2008) and Mollick et al. (2006) are papers about FDI inflows which also mention the same bias problem in their analysis. As Chiquiar (2005) suggests, NAFTA (now called USMCA) has given Mexico's regions more economic independence and thus reduced the importance of Mexico City as the country's market leader. Nevertheless, FDI inflows have been strongly concentrated in few states. For example, the top five FDI inflow attractors in the country, namely Mexico City, Estado de Mexico, Nuevo Leon, Chihuahua, and Jalisco, together received around $50 \%$ of the total FDI inflows into the country during the period analyzed in this study.

The regression model estimation also includes alternative wage as a control variable. In terms of the former, the approach of Cabral et al. (2016) is applied in considering 
Table 2 Statistics period summary: 2005-2018. Source: Author's calculations using data from the INEGI and the Ministry of Economy

\begin{tabular}{|c|c|c|c|c|c|}
\hline Variables & Observations & Mean & Std. dev. & Min & Max \\
\hline \multicolumn{6}{|l|}{ Dependent variables } \\
\hline \multicolumn{6}{|l|}{ Employment } \\
\hline Secondary school or lower degree, manufacturing sector & 1792 & 189,974 & 320,008 & 9231 & $5,968,144$ \\
\hline At least high-school, manufacturing sector & 1792 & 68,294 & 144,871 & 2292 & $2,830,844$ \\
\hline Secondary school or lower degree, services sector & 1792 & 377,279 & 623,435 & 66,047 & $11,558,841$ \\
\hline At least high-school, services sector & 1792 & 292,862 & 572,942 & 43,823 & $11,004,266$ \\
\hline \multicolumn{6}{|l|}{ Monthly wage (average in MXN) } \\
\hline Secondary school or lower degree, manufacturing sector & 1792 & 4194 & 965 & 1711 & 11,470 \\
\hline At least high-school, manufacturing sector & 1792 & 6974 & 2351 & 1712 & 17,764 \\
\hline Secondary school or lower degree, services sector & 1792 & 4419 & 956 & 2024 & 9026 \\
\hline At least high-school, services sector & 1792 & 7773 & 2335 & 1894 & 15,236 \\
\hline \multicolumn{6}{|l|}{ Regressors } \\
\hline Population & 1792 & 3629,924 & 3056,025 & 540,154 & $17,694,804$ \\
\hline \multicolumn{6}{|l|}{ Alternative monthly wage (average in MXN) } \\
\hline Secondary school or lower degree, manufacturing sector & 1792 & 4245 & 765 & 2689 & 6569 \\
\hline At least high-school, manufacturing sector & 1792 & 6928 & 1192 & 4583 & 10,138 \\
\hline Secondary school or lower degree, services sector & 1792 & 4454 & 761 & 3011 & 6662 \\
\hline At least high-school, services sector & 1792 & 7724 & 1314 & 5333 & 11,129 \\
\hline \multicolumn{6}{|l|}{ Foreign direct investment } \\
\hline Manufacture (Millions of current dollars) & 1792 & 115.2 & 225.8 & -326.8 & 3185.8 \\
\hline Services (Millions of current dollars) & 1792 & 51.9 & 196.3 & -2450.0 & 2693.6 \\
\hline
\end{tabular}

state-level real wages of employees in the formal sector $(2013=100)$. Regarding the latter, it is possible to estimate a spatial weighted average of wages except for the state $i$ based on the distance that exists between the government statehouse $i$ and government statehouse in the remaining states. Moreover, control variables also include population levels of each state. All these variables in the dataset are available on a quarterly basis. Carlino and Mills (1987), Clark and Murphy (1996) and Lastly, Boarnet (2005) provide arguments to justify why population size is an important factor to explain employment growth.

It is relevant to mention that lagged values for some of the independent variables are included in the econometric models, since it is reasonable to expect that employment levels recorded in a specific quarter of the year are not the result of the explanatory variables of that same quarter, instead it is the result from the past fluctuations of those variables. The optimal lag length for each independent variable was selected through the application of the Akaike information criterion.

\section{Empirical results}

\subsection{The effect of FDI on employment}

The aim of this study is to analyze the impact of FDI on different types of employment. Table 3 presents FE and PCSE regression results for the four different employment-dependent variables covered in this study: low-skilled and high-skilled employment in the manufacturing and service sectors. The estimates are obtained throughout a panel that includes the entire country (32 states) and for a panel dataset that includes just 10 states which are the most important receivers of FDI in the country either in manufacture or service sectors. In this sense, Table 3 shows regressions coefficient estimates for the entire country as well as for the top 10 FDI states receivers. The exercise for the top 10 FDI states receivers is included, since FDI inflows received in the country are highly concentrated in few states. ${ }^{1}$ According to the Akaike criterion, test results indicate that just one lag period should be included in the regression for the FDI

\footnotetext{
$\overline{{ }^{1} \text { Moreover, to test the robustness of the results, estimates were also obtained }}$ for the top five FDI states receivers in the country, but they are not reported in the table because the lack of space and because results are similar to those obtained for the entire country and for the top 10 states reported in Table 3. Results for the top five FDI states receivers are available upon request.
} 


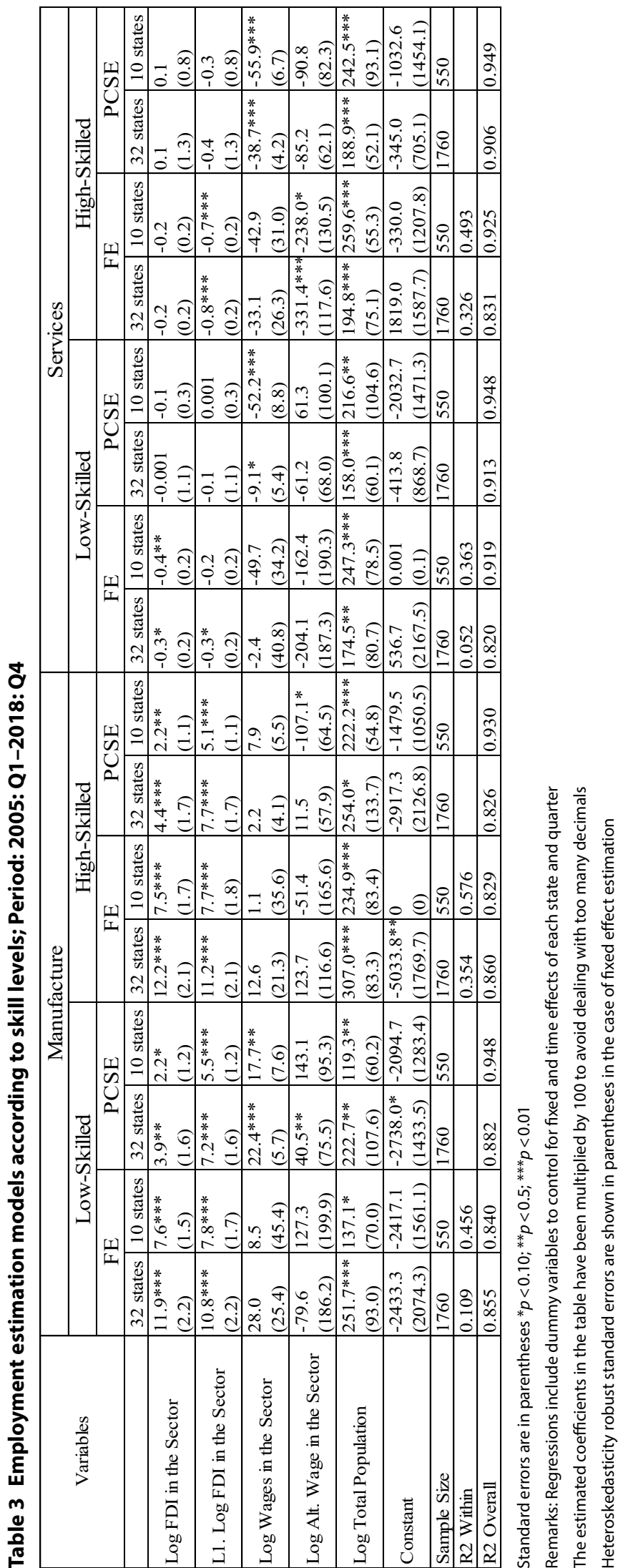


independent variable, no matter if the model is estimated for the entire country or the top 10 FDI states receivers.

Results in Table 3 indicate that manufacturing FDI has a positive and statistically significant effect on highskilled manufacture employment, such estimates are consistent either for fixed effects or PCSE models either for the entire country or for the top 10 FDI states receivers. Such results are aligned with those found in most of the previous research studies mentioned in Sect. 2, which argue that FDI inflows in this sector increase the demand for low- and high-skilled jobs. Lagged values presented a higher coefficient than the contemporary FDI in the case of the PCSE estimates. Similar results for Mexico in which FDI inflows in the manufacture sector have a positive effect on employment in the same sector can be found in Waldkirch et al. (2009), who analyze the nonmaquiladora manufacturing activities in Mexico during the 1994-2006 period. In a different study about Mexico, Cota (2011) also finds that FDI inflows had a positive effect on high-skilled employment in the manufacture industry. International literature for different countries with similar results can be found in Bailey and Driffield (2007), Raouf and Hafid (2014), Hoxhaj et al. (2016) and Souare and Zhou (2016).

The results for the service sector either for low- or high-skilled employment, shown in the right-hand column in Table 3, are not very conclusive, although, in terms of fixed effects the FDI inflow effects on the different employment categories are negative and statistically significant. Nevertheless, once the correction of econometric problems is considered implementing the PCSE, it is not possible to make inferences about the effects of FDI inflows on the low- or high-skilled employment in the service sector since coefficients are not statistically significant. Results for the top 10 FDI states receivers are also consistent with results obtained for the entire country, either for the fixed effects or PCSE models.

The control variables included in the econometric model highlight the fact that wages present a positive and statistically significant effect only for the PCSE for the low-skilled manufacture sector jobs. In this case, results are also consistent for the entire country and for the top 10 FDI states.

Alternative wages are not statistically significant in most cases. In the case of manufacturing, results are positive and statistically significant for low-skilled jobs, but negative for high-skilled jobs in the case of the top 10 states. Only in the high-skilled service sector the effect of the alternative wages is negative and significant either for the entire country or for the top 10 states when they are estimated with FE. As expected, a negative impact on the level of employment by the variable alternative wages is observed. This is consistent with the idea that wage differences among regions encourages migration, and implies that when wages increase in the rest of the country, except in state 'i' (alternative wage), then workers in state ' $i$ ' have an incentive to leave the state, where wages should subsequently increase to keep more workers from migrating. Lastly, similar to Boarnet (2005), the population variable is positive and significant across all estimates, no matter the econometric model or the number of states included in the analysis.

\subsection{The effect of FDI on wages}

Table 4 regression results show how FDI has an impact on the different wage categories in the manufacturing and service sectors. As in Table 3, each econometric model is estimated either for the entire country or for the top 10 FDI states receivers in the country. ${ }^{2}$ Regarding the number of lags, Akaike criterion indicates similar results as the one obtained for Table 3, no matter if the model is estimated for the entire country or the top 10 FDI states.

In the case of estimates for the entire country, results for the manufacturing sector indicate that FDI inflows either contemporaneous or lagged values both have statistically significant effects on low-skilled wages and such effect are consistent for FE and PCSE models. In the case of top 10 FDI states estimates, results show only a positive and statistically significant effect just for the lagged value of FDI in the PCSE estimates.

Results for the entire country could be an indicator that FDI inflows are replacing low-skilled jobs in the manufacturing sector. Such effect could indicate that new FDI inflows in the manufacturing sector could be creating new jobs that are not well paid. Literature about other countries, such as Bailey and Driffield (2007) and Onaran (2012) found similar results. Estimates obtained in Table 4 also indicate that FDI inflows in the manufacturing sector have no impact on high-skilled wages. Such results are consistent throughout FE and PCSE models, no matter if estimates are for the entire country or for the top 10 FDI states receivers.

Regarding the service sector, wages estimates are not very conclusive for low-skilled and high-skilled wages, regardless of the data used for the estimates, be the entire country or the top 10 FDI states receivers. Such results are inconclusive because in the FE model the FDI variable has a positive and significant effect, but when the PCSE model is estimated, the coefficients are no longer significant. As in the case of service sector employment, results do not allow for a strong inference to be made in terms of the effect of FDI inflows on low-skilled wages. FDI inflows to the service sector are found to increase wages

\footnotetext{
${ }^{2}$ To be consistent with Table 3, estimates were also obtained for the top five FDI states receivers in the country, but they are not reported here. Results are available upon request.
} 


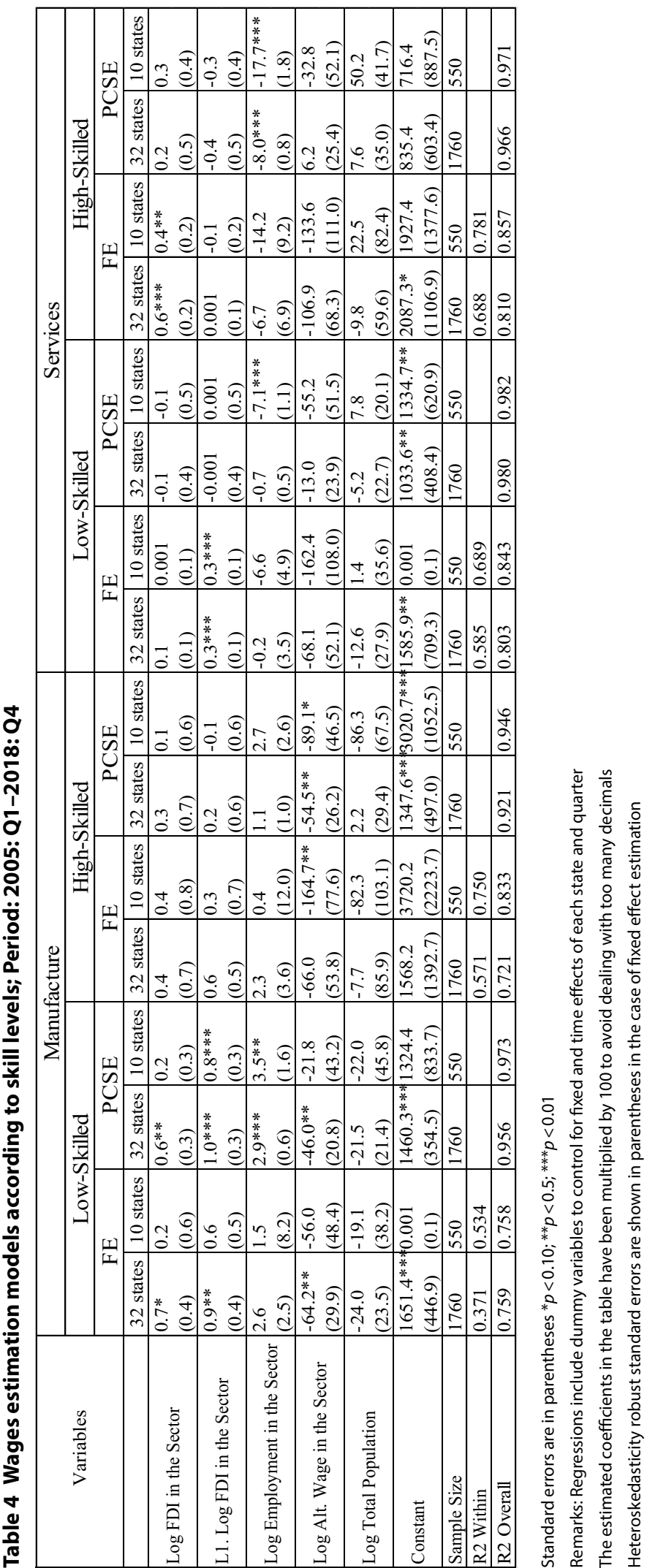


Table 5 The effect of FDI on the labor market; A control and treatment effect comparison

\begin{tabular}{|c|c|c|c|c|c|c|c|c|c|c|c|c|c|c|c|c|c|}
\hline & \multicolumn{8}{|c|}{ Manufacture } & \multicolumn{8}{|c|}{ Services } \\
\hline & & \multicolumn{4}{|c|}{ Employment } & \multicolumn{4}{|c|}{ Wages } & \multicolumn{4}{|c|}{ Employment } & \multicolumn{4}{|c|}{ Wages } \\
\hline & & \multicolumn{2}{|c|}{ Low-skilled } & \multicolumn{2}{|c|}{ High-skilled } & \multicolumn{2}{|c|}{ Low-skilled } & \multicolumn{2}{|c|}{ High-skilled } & \multicolumn{2}{|c|}{ Low-skilled } & \multicolumn{2}{|c|}{ High-skilled } & \multicolumn{2}{|c|}{ Low-skilled } & \multicolumn{2}{|c|}{ High-skilled } \\
\hline & & $\begin{array}{c}\text { Fixed } \\
\text { Effects }\end{array}$ & PCSE & $\begin{array}{c}\text { Fixed } \\
\text { Effects }\end{array}$ & PCSE & $\begin{array}{c}\text { Fixed } \\
\text { Effects }\end{array}$ & PCSE & \begin{tabular}{|c|} 
Fixed \\
Effects \\
\end{tabular} & PCSE & \begin{tabular}{c|} 
Fixed \\
Effects \\
\end{tabular} & PCSE & \begin{tabular}{|c|} 
Fixed \\
Effects \\
\end{tabular} & PCSE & \begin{tabular}{|c|} 
Fixed \\
Effects \\
\end{tabular} & PCSE & \begin{tabular}{|c|} 
Fixed \\
Effects \\
\end{tabular} & PCSE \\
\hline \multirow{4}{*}{32 states } & Control & 15.70 & 15.64 & 15.87 & 15.71 & 13.51 & 13.48 & & & 15.35 & & 15.47 & & 12.55 & & 12.53 & \\
\hline & \begin{tabular}{|l|} 
Treatment \\
\end{tabular} & 21.26 & 20.54 & 21.29 & 20.63 & 18.62 & 18.59 & & & 19.44 & & 19.90 & & 19.05 & & 19.44 & \\
\hline & Difference & 5.55 & 4.91 & 5.42 & 4.92 & 5.11 & 5.11 & & & 4.09 & & 4.42 & & 6.51 & & 6.91 & \\
\hline & $\begin{array}{l}\text { Signif. at the } \\
1 \% \text { level }\end{array}$ & Yes & Yes & Yes & Yes & Yes & Yes & & & Yes & & Yes & & Yes & & Yes & \\
\hline & & & & & & & & & & & & & & & & & \\
\hline \multirow{4}{*}{10 states } & Control & 14.90 & 15.07 & 15.54 & 15.54 & & 13.42 & & & 15.71 & & 15.76 & & 10.36 & & 13.17 & \\
\hline & Treatment & 20.87 & 20.17 & 20.86 & 20.13 & & 18.15 & & & 19.34 & & 19.79 & & 18.81 & & 18.72 & \\
\hline & Difference & 5.98 & 5.10 & 5.32 & 4.58 & & 4.72 & & & 3.63 & & 4.03 & & 8.45 & & 5.55 & \\
\hline & $\begin{array}{l}\text { Signif. at the } \\
1 \% \text { level }\end{array}$ & Yes & Yes & Yes & Yes & & Yes & & & Yes & & Yes & & Yes & & Yes & \\
\hline
\end{tabular}

Columns in grey indicate that FDI in Tables 3 and 4 was not statistically significant, in such scenario the "control effect" model and the "treatment effect" models were equal

in both the high-skilled and low-skilled employment in the case of FE models.

Control variable results indicate that low-skilled jobs in the manufacturing sector have a positive and statistically significant effect on wages. Such results come exclusively from the PCSE model. Estimates for high-skilled jobs are not significant in either the FE or PCSE models. Results are aligned for the entire country panel dataset or the top 10 FDI states dataset. In the case of the service sector, results show that employment level generates a negative and statistically significant effect on wages. As expected, such results are obtained just in the PCSE models in the case of high-skilled jobs.

Regarding alternative wages, results indicate that the alternative wages variable has a negative and statistically significant effect on wages in the manufacturing sector, either for low or high-skilled wages in most econometric models, regardless of the panel dataset included in the regression. Such negative coefficient between alternative wages and wages indicates that an increase in manufacturing wages in state " $\mathrm{i}$ " creates a negative effect on wages in the same sector in the remaining states, which is contrary to expectations. When the exercise is replicated for the 10 states that received the higher FDI inflows from each of the sectors, the results remain consistent with those that have been discussed. In the case of the service sector, the alternative wage variable is not statistically significant for any model or panel dataset. Regarding the population variable, results indicate that such variable is not statistically significant across models, regardless of the econometric model or dataset used, and such results are consistent for the manufacturing and service sectors.

The dependent variables in the econometric models in this study are employment and wages. Table 5 compares those econometric models when they are estimated including the FDI independent variable, and when such variable is excluded from the models. The difference obtained in the estimated dependent variable once both types of models are estimated allows us to identify the effect that FDI is having either on employment or wages. When the econometric models do not include the FDI variable they are called "control effect" models, and when the FDI is included, they are referred to as "treatment effect" models.

Once the estimated betas are obtained for the "control effect" model, then an expected employment mean, and an expected wage mean is obtained for each of the states in the entire country. Using the estimated means in employment and wages obtained for each state, a general mean is obtained for both dependent variables. The same process is repeated for the "treatment effect" model and a general mean is obtained again for both dependent variables. Such general mean values are presented in the "control effect" and "treatment effect" cells in Table 5 for each of the econometric models implemented in this study. The row labelled "difference" is just the difference between the general mean obtained for the "control effect" model and the general mean in the "treatment effect" model. Lastly, a t-test is implemented to estimate if there is a statistical difference between both means. ${ }^{3}$ If so, then it is indicated as "yes" and then it is concluded that FDI has a statistically significant effect either on employment or wage levels. The same exercise is repeated for each econometric model estimated in the study, and for the econometric panel when 32 or 10 states are included in the study. Masso et al. (2008), Becker and Muendler (2008), Lu et al. (2017) and Bannò et al. (2014) are some

${ }^{3}$ An $\alpha=0.01$ is used in the t-test. 
studies that analyze the applications of treatment effects, those studies include FDI as a relevant variable.

\section{Conclusion}

It has been always important to analyze the effect of FDI inflows on labor markets in the host economy. Few studies in the literature have been focused on separating the Mexican labor market according to employee skill categories (education level) and analyzing how FDI inflows influence them. The objective of this study is to contribute to filling this gap by separating employment and wages from the manufacture and service sectors into low- and high-skilled categories and analyzing how FDI inflows into these sectors impact employment and wages of those categories. The study is a panel data analysis made up of the 32 Mexican states, spanning from 2005 to 2018. Manufacturing and service sectors are analyzed, as those are the country's largest receivers of FDI. During the analyzed period in this study, those sectors captured between 60 and $90 \%$ of the country's total FDI and created the highest number of jobs among all economic sectors in the country.

When the panel dataset is estimated for the entire country, employment results indicate that an increase of FDI inflows into the manufacture sector creates an increase in both low-skilled and high-skilled employment. The effect persists even when the sample is reduced to the 10 states that received the most FDI in the period under study. Low- and high-skilled employment results in the service sector are inconclusive across the econometric models, regardless of sample reduction. A positive effect in wages is found for FDI inflows received by the manufacture sector when estimated for the entire country, and no statistical effect is captured in highskilled wages. Lastly, it is found that low-skilled and highskilled wages results are inconclusive across econometric models, regardless of the sample reduction.

The study of the effect of FDI inflows on the Mexican labor market is a topic that deserves more attention than in other economies, as the proximity of Mexico to the US, the most important economy in the world, makes it an attractive host economy for their investment compared to other countries. Additionally, lower wages and the trade agreement with the US and Canada, have made Mexico an important place to attract foreign companies. Therefore, given the importance of Mexico in the international arena to attract FDI inflows, it is relevant for Mexican policy makers to analyze in more detail the effects that FDI inflows have on employment and wages in specific sectors and geographic regions, in order to develop better policies for the country in these major areas.

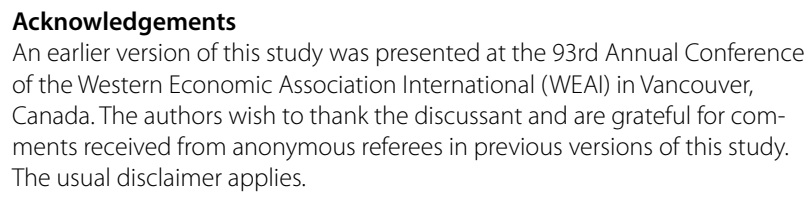

\section{Copyright and intellectual property}

We declare this manuscript does not infringe the copyright, moral rights, or other intellectual property rights of any other person.

In addition, we want to testify that this paper is original and has not incurred in any type of plagiarism.

Furthermore, we would like to declare that this manuscript has been submitted only to this journal and has not been published or partially published elsewhere.

\section{Authors' contributions}

ES-Has used in a different research paper the econometric model used in this paper. In addition, he has worked previously in topics related with Foreign Direct Investment. So, he provided the idea to analyze the effect of FDI on Employment. In addition, he was involved in the literature review, introduction, and conclusion. TO_Provided some help with the literature review section, interpretation results and with style correction of the text, as English is his native language. $\mathrm{HZ}$ - Collected the data and was in charge of the econometrics in this paper. All authors read and approved the final manuscript.

\section{Availability of data and materials}

The data used in this paper is open to public in different Mexican websites. Information about how to get such data is mentioned in the paper in the data section. In addition, it is mentioned in the paper the following statement: "The datasets used and/or analyzed during the current study are available from the corresponding author on reasonable request."

\section{Ethics approval and consent to participate}

The authors of this study declare this manuscript does not infringe the copyright, moral rights, or other intellectual property rights of any other person. The authors of this study testify that this paper is original and has not incurred in any type of plagiarism. The authors of this study declare that the article is original, has not already been published in a journal, and is not currently under consideration by another journal The authors of this study agree to the terms of the SpringerOpen Copyright and License Agreement.

\section{Consent for publication \\ Not applicable.}

\section{Competing interests and funding}

We declare that we have not received any type of funding or grant for the elaboration of this research paper. For that reason, we do not have any conflict of interest, including any type of financial interest related with the paper.

\section{Author details}

${ }^{1}$ EGADE Business School, Tecnologico de Monterrey, Ave. Rufino Tamayo, CP. 66269 Garza Garcia, NL, Mexico. ${ }^{2}$ Deloitte Mexico, Ave. Juarez, CP. 64000 Monterrey, NL, Mexico.

\section{Appendix}

See Tables 6, 7 and Fig. 2. 
Table 6 Employment distribution across Mexican States; Average values, 2005-2018. Source: Author's elaboration with ENOE data

\begin{tabular}{|c|c|c|c|c|c|c|c|c|}
\hline \multirow[t]{2}{*}{ State } & \multicolumn{4}{|c|}{ Manufacture employment } & \multicolumn{4}{|c|}{ Services employment } \\
\hline & Low skilled & $\%$ & High skilled & $\%$ & Low skilled & $\%$ & High skilled & $\%$ \\
\hline Estado de Mexico & 820,626 & 13.5 & $1,692,239$ & 14.0 & 311,789 & 14.3 & $1,143,951$ & 12.2 \\
\hline Mexico City & 303,848 & 5.0 & $1,113,072$ & 9.2 & 179,402 & 8.2 & $1,210,375$ & 12.9 \\
\hline Jalisco & 426,909 & 7.0 & 731,174 & 6.1 & 149,888 & 6.9 & 539,360 & 5.8 \\
\hline Veracruz & 204,052 & 3.4 & 622,907 & 5.2 & 80,992 & 3.7 & 437,722 & 4.7 \\
\hline Puebla & 307,481 & 5.1 & 432,779 & 3.6 & 90,090 & 4.1 & 319,540 & 3.4 \\
\hline Nuevo Leon & 344,895 & 5.7 & 598,906 & 5.0 & 106,720 & 4.9 & 324,198 & 3.5 \\
\hline Guanajuato & 403,055 & 6.6 & 460,579 & 3.8 & 102,897 & 4.7 & 265,470 & 2.8 \\
\hline Tamaulipas & 166,195 & 2.7 & 335,442 & 2.8 & 91,132 & 4.2 & 254,266 & 2.7 \\
\hline Baja California & 209,704 & 3.4 & 288,887 & 2.4 & 82,998 & 3.8 & 238,976 & 2.6 \\
\hline Chihuahua & 247,651 & 4.1 & 295,606 & 2.4 & 90,648 & 4.1 & 227,961 & 2.4 \\
\hline Sinaloa & 91,119 & 1.5 & 253,425 & 2.1 & 38,882 & 1.8 & 232,437 & 2.5 \\
\hline Sonora & 139,969 & 2.3 & 251,248 & 2.1 & 60,714 & 2.8 & 222,294 & 2.4 \\
\hline Chiapas & 104,600 & 1.7 & 283,913 & 2.4 & 21,361 & 1.0 & 233,473 & 2.5 \\
\hline Michoacan & 245,059 & 4.0 & 502,765 & 4.2 & 62,376 & 2.9 & 332,723 & 3.6 \\
\hline Coahuila & 214,302 & 3.5 & 340,929 & 2.8 & 89,849 & 4.1 & 275,060 & 2.9 \\
\hline Guerrero & 137,781 & 2.3 & 282,567 & 2.3 & 25,853 & 1.2 & 236,446 & 2.5 \\
\hline Oaxaca & 185,636 & 3.1 & 311,022 & 2.6 & 34,972 & 1.6 & 228,359 & 2.4 \\
\hline Tabasco & 53,490 & 0.9 & 212,541 & 1.8 & 20,833 & 1.0 & 172,345 & 1.8 \\
\hline Hidalgo & 124,788 & 2.1 & 223,342 & 1.8 & 35,036 & 1.6 & 169,701 & 1.8 \\
\hline San Luis Potosi & 127,974 & 2.1 & 228,552 & 1.9 & 41,564 & 1.9 & 159,978 & 1.7 \\
\hline Yucatan & 143,443 & 2.4 & 276,569 & 2.3 & 30,559 & 1.4 & 175,605 & 1.9 \\
\hline Quintana Roo & 36,305 & 0.6 & 221,175 & 1.8 & 11,396 & 0.5 & 171,463 & 1.8 \\
\hline Morelos & 68,072 & 1.1 & 216,530 & 1.8 & 28,209 & 1.3 & 153,139 & 1.6 \\
\hline Queretaro & 127,682 & 2.1 & 188,952 & 1.6 & 54,585 & 2.5 & 151,358 & 1.6 \\
\hline Durango & 76,363 & 1.3 & 143,698 & 1.2 & 20,251 & 0.9 & 103,373 & 1.1 \\
\hline Aguascalientes & 491,166 & 8.1 & 917,986 & 7.6 & 224,607 & 10.3 & 858,809 & 9.2 \\
\hline Nayarit & 33,764 & 0.6 & 122,654 & 1.0 & 11,427 & 0.5 & 103,612 & 1.1 \\
\hline Tlaxcala & 94,202 & 1.5 & 105,608 & 0.9 & 36,114 & 1.7 & 94,871 & 1.0 \\
\hline Zacatecas & 53,106 & 0.9 & 125,800 & 1.0 & 12,821 & 0.6 & 89,891 & 1.0 \\
\hline Baja California Sur & 31,268 & 0.5 & 101,367 & 0.8 & 15,652 & 0.7 & 94,966 & 1.0 \\
\hline Campeche & 26,722 & 0.4 & 86,395 & 0.7 & 6,909 & 0.3 & 72,536 & 0.8 \\
\hline Colima & 37,943 & 0.6 & 104,294 & 0.9 & 14,885 & 0.7 & 77,324 & 0.8 \\
\hline Total & $6,079,169$ & 100 & $12,072,919$ & 100 & $2,185,413$ & 100 & $9,371,581$ & 100 \\
\hline
\end{tabular}

Figure 2 shows the FDI flows received by each state along all the period analyzed in this study. As can be seen, FDI inflows show sharp changes in most of the states during the 2008-2009 economic crisis as well as during the 2013-2014 period when some economic sectors deregulated. Some other states such as Mexico
City shows permanent swings along the entire analyzed period. All those constant sharp changes shown in most states can be helpful to justify the inclusion of difference-in-difference model into the analysis. 
Table 7 Rank average monthly real wage across Mexican States, 2005-2018; Economic sectors and labor skills. Source: Author's elaboration with ENOE Data

\begin{tabular}{|c|c|c|c|c|c|c|c|}
\hline \multicolumn{4}{|c|}{ Manufacture sector } & \multicolumn{4}{|c|}{ Services employment } \\
\hline Entities & Low skilled & Entities & High skilled & Entities & Low skilled & Entities & High skilled \\
\hline Baja California & 4301 & Coahuila & 7549 & Baja California & 4538 & Baja California Sur & 7696 \\
\hline Baja California Sur & 4254 & Tamaulipas & 6698 & Baja California Sur & 4480 & Sinaloa & 7085 \\
\hline Nuevo Leon & 4101 & Hidalgo & 6550 & Sinaloa & 4146 & Coahuila & 7057 \\
\hline Coahuila & 3892 & Nuevo Leon & 6471 & Sonora & 3980 & Sonora & 7036 \\
\hline Sonora & 3841 & Baja California & 6285 & Quintana Roo & 3947 & Campeche & 6978 \\
\hline Chihuahua & 3772 & Chihuahua & 6265 & Chihuahua & 3912 & Quintana Roo & 6942 \\
\hline Guanajuato & 3760 & Sonora & 6130 & Nuevo Leon & 3829 & Michoacán & 6919 \\
\hline Sinaloa & 3747 & San Luis Potosi & 5987 & Michoacán & 3722 & Hidalgo & 6807 \\
\hline Tabasco & 3627 & Tabasco & 5986 & Colima & 3683 & Chihuahua & 6740 \\
\hline Colima & 3613 & Michoacán & 5887 & Tabasco & 3675 & Chiapas & 6671 \\
\hline Tamaulipas & 3575 & Sinaloa & 5877 & Coahuila & 3664 & Baja California & 6656 \\
\hline Quintana Roo & 3405 & Quintana Roo & 5849 & Campeche & 3592 & Colima & 6564 \\
\hline Jalisco & 3392 & Baja California Sur & 5702 & Nayarit & 3557 & Tabasco & 6476 \\
\hline Durango & 3388 & Veracruz & 5598 & Hidalgo & 3420 & Nayarit & 6351 \\
\hline Michoacán & 3379 & Yucatan & 5353 & Durango & 3389 & Yucatan & 6303 \\
\hline Average & 3225 & Average & 5259 & Average & 3383 & Nuevo Leon & 6069 \\
\hline Hidalgo & 3207 & Colima & 5159 & Tamaulipas & 3337 & Durango & 5912 \\
\hline Aguascalientes & 3111 & Jalisco & 5132 & Jalisco & 3315 & Average & 5862 \\
\hline Nayarit & 3061 & Mexico City & 5119 & Guanajuato & 3173 & Tamaulipas & 5854 \\
\hline Mexico City & 3059 & Nayarit & 4916 & Chiapas & 3141 & San Luis Potosi & 5736 \\
\hline San Luis Potosi & 3042 & Durango & 4783 & Mexico City & 3141 & Zacatecas & 5719 \\
\hline Veracruz & 3015 & Guanajuato & 4712 & Guerrero & 3131 & Mexico City & 5446 \\
\hline Querétaro & 2995 & Oaxaca & 4635 & San Luis Potosi & 3114 & Jalisco & 5277 \\
\hline Zacatecas & 2773 & Querétaro & 4629 & Veracruz & 3040 & Oaxaca & 5145 \\
\hline Campeche & 2765 & Puebla & 4612 & Yucatan & 3035 & Veracruz & 4954 \\
\hline Puebla & 2737 & Campeche & 4497 & Oaxaca & 3028 & Puebla & 4819 \\
\hline Estado de Mexico & 2692 & Chiapas & 4496 & Querétaro & 2992 & Guanajuato & 4814 \\
\hline Tlaxcala & 2612 & Aguascalientes & 4413 & Zacatecas & 2860 & Tlaxcala & 4771 \\
\hline Chiapas & 2610 & Zacatecas & 4400 & Aguascalientes & 2805 & Aguascalientes & 4661 \\
\hline Yucatan & 2447 & Guerrero & 3910 & Estado de Mexico & 2801 & Guerrero & 4656 \\
\hline Guerrero & 2435 & Tlaxcala & 3809 & Puebla & 2794 & Querétaro & 4311 \\
\hline Oaxaca & 2386 & Estado de Mexico & 3684 & Tlaxcala & 2697 & Estado de Mexico & 3802 \\
\hline Morelos & 2193 & Morelos & 3197 & Morelos & 2315 & Morelos & 3372 \\
\hline
\end{tabular}

Real values, $(2013=100)$ 


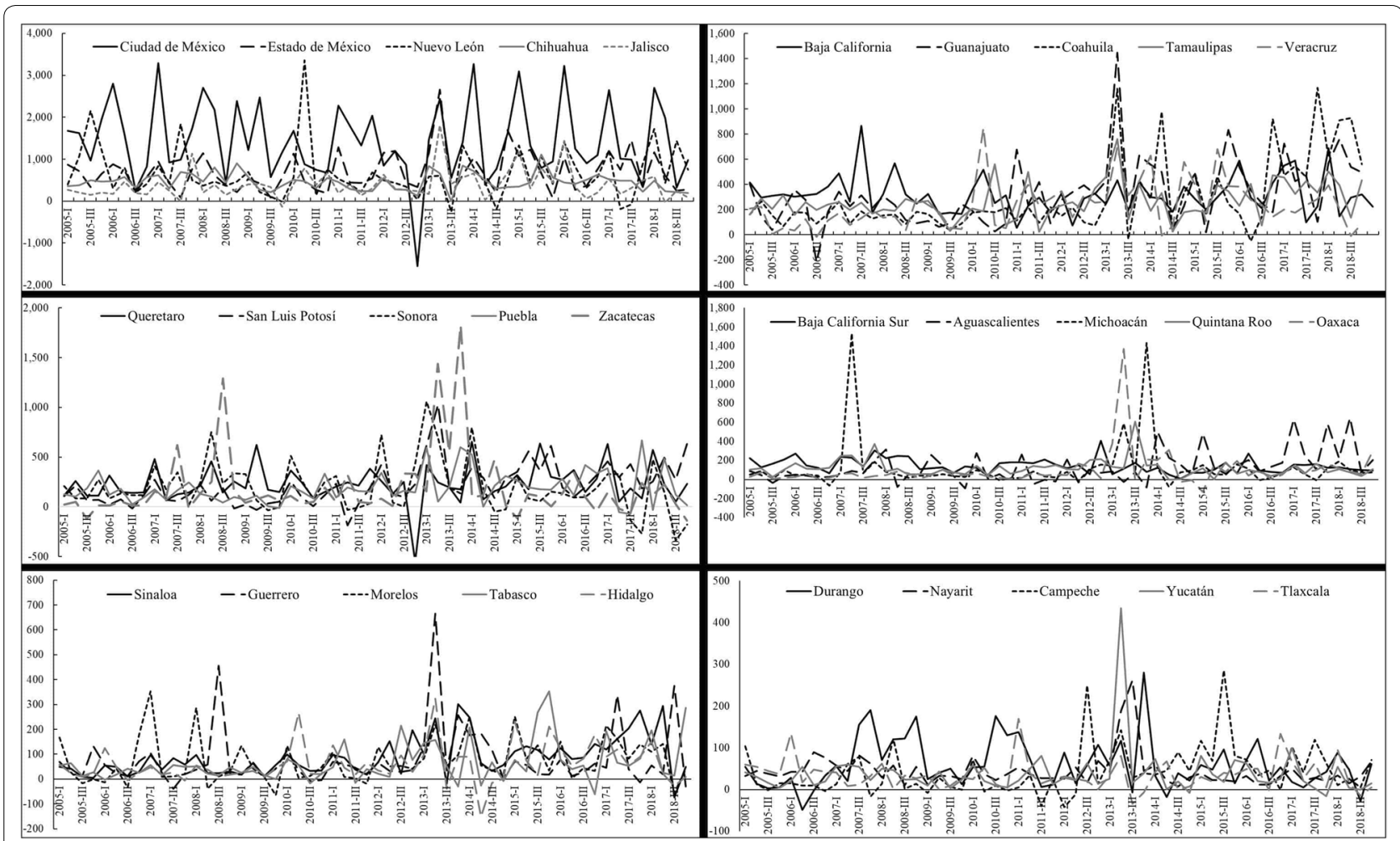

Fig. 2 FDI flows received by each state 2005-2018

Received: 19 April 2019 Accepted: 19 June 2020

Published online: 13 July 2020

\section{References}

Bailey, D., Driffield, N.: Industrial policy, FDI and employment: still 'missing a strategy. J. Ind. Compet. Trade 7(3-4), 189-211 (2007). https://doi. org/10.1007/s10842-006-7185-8

Bandick, R., Karpaty, P.: Employment effects of foreign acquisition. Int. Rev. Econ. Finance 20(2), 211-224 (2011)

Bannò, M., Piscitello, L., Amorim, Varum C.: The impact of public support on SMEs' outward FDI: evidence from Italy. J. Small Bus. Manage. 52(1), 22-38 (2014)

Beck, N., Katz, J.N.: What to do (and not to do) with time-series cross-section data. Am. Polit. Sci. Rev. 89(3), 634-647 (1995)

Becker, S.O., Muendler, M.-A.: The effect of FDI on job security. BE J. Econ. Anal. Policy 8(1) (2008)

Bellak, C.: The measurement of foreign direct investment: a critical review. Int. Trade J. 12(2), 227-257 (1998)

Blanton, R.G., Blanton, S.L.: Rights, institutions, and foreign direct investment: an empirical assessment. Foreign Policy Anal. 8(4), 431-451 (2012)

Boarnet, M.G.: An empirical model of intrametropolitan population and employment growth. Stud. Reg. Sci. 73(2), 135-152 (2005). https://doi. org/10.1111/j.1435-5597.1994.tb00607.x

Bogliaccini, J.A., Egan, P.J.W.: Foreign direct investment and inequality in developing countries: does sector matter? Econ. Polit. 29(3), 209-236 (2017). https://doi.org/10.1111/ecpo.12098

Cabral, R., Mollick, A.V., Saucedo, E.: Violence in Mexico and its effects on labor productivity. Ann. Reg. Sci. 56(2), 317-339 (2016). https://doi. org/10.1007/s00168-016-0741-1

Cameron, A.C., Trivedi, P.K.: Microeconometrics using Stata, revised edition. StataCorp LP (2010)
Carlino, G.A., Mills, E.S.: The determinants of county growth. J. Reg. Sci. 27(1), 39-54 (1987). https://doi.org/10.1111/j.1467-9787.1987.tb01143.x Chiquiar, D.: Why Mexico's regional income convergence broke down. J. Dev. Econ. 77(1), 257-275 (2005)

Clark, D.E., Murphy, C.A.: Countywide employment and population growth: an analysis of the 1980s. J. Reg. Sci. 36(2), 235-256 (1996). https://doi. org/10.1111/j.1467-9787.1996.tb01267.x

Cota, J.E.M.: Impact of foreign direct investment on the growth of manufacturing in Mexico. Problemas Del Desarrollo 42(167), 45-69 (2011)

Feenstra, R.C., Hanson, G.H.: Foreign direct investment and relative wages: evidence from Mexico's Maquiladoras. J. Int. Econ. 42(3-4), 371-393 (1997)

Girma, S.: Safeguarding jobs? Acquisition FDI and employment dynamics in the UK manufacturing. Rev. World Econ. 141(1), 165-178 (2005)

Girma, S., Thompson, S., Wright, W.: Why are productivity and wages higher in foreign firms? Econ. Soc. Rev. 33(1), 93-100 (2002)

Hanousek, J., Kočenda, E., Maurel, M.: Direct and indirect effects of FDI in emerging european markets: a survey and meta-analysis. Econ. Syst. 35(3), 301-322 (2011)

Hanson, G.H.: US-Mexico integration and regional economies: evidence from Border-City Pairs. J. Urban Econ. 50(2), 259-287 (2001)

Hoxhaj, R., Marchal, L., Seric, A.: FDI and migration of skilled workers towards developing countries: firm-level evidence from Sub-Saharan Africa. J. Afr. Econ. 25(2), 201-232 (2016). https://doi.org/10.1093/jae/ejv022

Inekwe, J.N.: FDI, employment and economic growth in Nigeria. Afr. Dev. Rev. 25(4), 421-433 (2013). https://doi.org/10.1111/1467-8268.12039

Jenkins, R.: FDI and employment in Vietnam. Transnatl. Corp. 15(1), 115-142 (2006)

Jordaan, J.A.: State characteristics and the locational choice of foreign direct investment: evidence from regional FDI in Mexico 1989-2006. Growth Change 39(3), 389-413 (2008). https://doi.org/10.111 $1 / j .1468-2257.2008 .00431 . x$ 
Lee, J.W., Wie, D.: Technological change, skill demand, and wage inequality: evidence from Indonesia. World Dev. 67, 238-250 (2015). https://doi. org/10.1016/j.worlddev.2014.10.020

Loría, E., Brito, L.: El Impacto de la Inversión Extranjera Directa en el Empleo Sectorial en México: Un Análisis Prospectivo. Análisis Económico 20(44), 5-34 (2005)

Lu, Y., Tao, Z., Zhu, L.: Identifying FDI Spillovers. J. Int. Econ. 107, 75-90 (2017)

Masso, J., Varblane, U., Vahter, P.: The effect of outward foreign direct investment on home-country employment in a low-cost transition economy. East. Eur. Econ. 46(6), 25-59 (2008)

Mollick, A.V., Ramos-Duran, R., Silva-Ochoa, E.: Infrastructure and FDI inflows into Mexico: a panel data approach. Glob. Econ. J. 6(1) (2006)

Nunnenkamp, P., Bremont, J.: FDI in Mexico: an empirical assessment of employment effects. No. 1328. Kiel Working Study (2007)

Onaran, Ö:: The effect of foreign affiliate employment on wages, employment, and the wage share in Austria. Rev. Polit. Econ. 24(2), 251-271 (2012). https://doi.org/10.1080/09538259.2012.664335

Owen, A.L., Yu, B.Y.: Regional differences in wage inequality across industries in China. Appl. Econ. Lett. 15(2), 113-116 (2008). https://doi. org/10.1080/13504850600770921

Pandya, S.S.: Labor markets and the demand for foreign direct investment. Int. Organ. 64(3), 389-409 (2010). https://doi.org/10.1017/s002081831 0000160

Radosevic, S., Varblane, U., Mickiewicz, T.: Foreign direct investment and its effect on employment in Central Europe. Transnatl. Corp. 12(1), 53-90 (2003)

Raouf, R., Hafid, H.: Relocation and inequalities between skilled and unskilled in Northern Countries: simulation using a CGE model. Int. J. Econ. Financ. Issues 4(4), 758-772 (2014)

Souare, M., Zhou, B.: Foreign-affiliate presence and skilled labour demand. IEEP 13(2), 233-254 (2016). https://doi.org/10.1007/s10368-014-0302-y
Turner, E., Martínez, J.: Inversión extranjera y empleo en México. Análisis económico 18(37), 221-239 (2003)

UNCTAD. World investment report 2016: investor nationality-policy challenges, UN, New York (2016). https://doi.org/10.18356/9d7da2eb-en

UNCTAD. World investment report 2017: investment and the digital economy, UN, New York (2017). https://doi.org/10.18356/e692e49c-en

UNCTAD. World investment report 2018: investment and new industrial policies, UN, New York (2018). https://doi.org/10.18356/ebb78749-en

Vergara, R., de Jesús, L., Carbajal, Y.: IED y Empleo en la Región Norte de México, 2004.1-2013.4 Un Análisis para el Sector Industrial. Equilibrio Económico 2(1), 65-94 (2015)

Villa, S.: Exploring the linkages between investment and employment in Moldova: a time series analysis. ILO Working Study, International Labor Organization (2010)

Waldkirch, A.: The effects of foreign direct investment in Mexico since NAFTA. World Econ. 33(5), 710-745 (2010). https://doi.org/10.111 1/j.1467-9701.2009.01244.x

Waldkirch, A.: Comparative advantage FDI? A host country perspective. Rev. World Econ. 147(3), 485-505 (2011). https://doi.org/10.1007/s1029 0-011-0096-8

Waldkirch, A., Nunnenkamp, P., Bremont, J.E.A.: Employment effects of FDI in Mexico's non-maquiladora manufacturing. J. Dev. Stud. 45(7), 1165-1183 (2009). https://doi.org/10.1080/00220380902952340

Yunus, N.M., Said, R., Azman-Saini, W.N.W.: Spillover effects of FDI and trade on demand for skilled labour in Malaysian manufacturing industries. Asian Acad. Manage. J. 20(2), 1-27 (2015)

\section{Publisher's Note}

Springer Nature remains neutral with regard to jurisdictional claims in published maps and institutional affiliations.

\section{Submit your manuscript to a SpringerOpen ${ }^{\circ}$ journal and benefit from:}

- Convenient online submission

- Rigorous peer review

- Open access: articles freely available online

- High visibility within the field

- Retaining the copyright to your article

Submit your next manuscript at $\boldsymbol{\nabla}$ springeropen.com 